\title{
Persistence of perennial ryegrass, tall fescue and cocksfoot following sequential annual sowings: pasture yield, composition and density in three establishment years under cattle grazing in Waikato
}

\author{
Gerald P. COSGROVE ${ }^{1, *}$, Michael R. TROLOVE ${ }^{2}$, Maryann R. STAINCLIFFE ${ }^{2}$, Katherine N. TOZER ${ }^{2}$ \\ ${ }^{1}$ AgResearch, Grasslands Research Centre, PB 11008, Palmerston North 4442, New Zealand \\ ${ }^{2}$ AgResearch, Ruakura Research Centre, PB 3123, Hamilton 3240, New Zealand \\ *Corresponding author: gerald.cosgrove@agresearch.co.nz
}

\begin{abstract}
Persistence is an important component of perennial pasture-grass productivity. Defining the traits that affect persistence is essential for improving pasture longevity through plant breeding and for identifying criteria that should be included in cultivar ranking indices. Compared with a conventional longitudinal study (a single study monitored over time), repeated annual sowings allow the effects on persistence of sowing year and the ensuing interactions between environment and age of pasture to be identified. An experiment commenced in 2016 in Waikato, in which eight cultivars of perennial ryegrass representing different ploidy, flowering date, and cultivar age, and one cultivar each of tall fescue and cocksfoot were sown in a randomised complete block design with four replicates, in autumn 2016, spring 2017 and autumn 2018. This paper reports interim data on pasture yield, composition and density measured in the autumn following each sowing, and for the 2018 sowing only, in the spring 6 months after sowing. For the three successive autumn measurements there were significant effects due cultivar, year of sowing and their interactions for all pasture variables. These effects indicate that very different pasture botanical and structural compositions were set up in the different sowing years. These differences in establishment may have consequences for the future resilience of these pastures under natural biotic and abiotic stressors.
\end{abstract}

Keywords: Lolium perenne, Festuca arundinacea, Dactylis glomerata, pasture establishment, ryegrass cultivar.

\section{Introduction}

Poor pasture persistence concerns many farmers in warmer and drier areas of New Zealand, especially the northern half of the North Island. A symposium in 2011 (Mercer 2011) reviewed the state of knowledge with respect to persistence, and considered research needs and opportunities. Identifying the primary (soil type, summer rainfall, $\mathrm{N}$-status, population dynamics) and secondary factors (weeds, pests and diseases, grazing management) was considered fundamental to understanding and managing for better persistence (Clark 2011). Furthermore, given changes in the genetic origins and functional types of perennial ryegrass (Lolium perenne) cultivars released from the 1990s onwards, plant genotype $\times$ defoliation interactions warrant renewed analysis (Edwards \& Chapman 2011). Few studies have assessed the ability of more recent cultivars to tolerate multiple stressors, especially studies conducted at multiple sites to identify relationships between biotic and abiotic factors (Chapman et al. 2015). Thom et al. (2011) identified the need for longer-term monitoring especially experiments investigating different establishment methods. Anecdotally, farmers in affected areas consider poor persistence is becoming more of an issue for them. While climate change (Chapman et al. 2011) and more intensive grazing systems (Edwards \& Chapman 2011) are often implicated, some farmers suggest poorer persistence in newer cultivars compared with older, ecotype-based ryegrasses (Tozer et al. 2011) although this is not supported by controlled studies (Lee et al. 2018). However, there are differences among cultivars in persistence of dry matter yield (Chapman et al. 2015) and ability to survive stressful environments (Thom et al. 1998).

Studies conducted to identify factors affecting persistence typically involve sowing a single experiment that is then monitored over time i.e. a 'longitudinal' study (e.g. Tozer et al. 2014; Lee et al. 2017). In such a design there can be confounding effects between the uncontrolled environmental factors that occur during the establishment phase and the timing of subsequent episodic stressors such as drought, insect or disease pressures i.e. there is no replication in time. Successive annual sowings could allow the effects of establishment-year and age of pasture when episodic stressors occur to be disentangled and better identify critical factors affecting persistence.

To meet these challenges, and to identify persistence traits appropriate for including in cultivar ranking indices such as the Forage Value Index (Chapman et al. 
2017), a long-term trial was initiated at two sites. This paper reports dry matter yield, botanical composition and sward structure in autumn following each of three annual sowings in Waikato. Equivalent data for the Canterbury site have recently been reported (Maxwell et al. 2018).

\section{Materials and Methods}

Two, long-term pasture persistence experiments have been set up, one commencing in 2015 under sheepgrazing in Canterbury, near Lincoln (Maxwell et al. 2018), and the other commencing in 2016 under rotational cattle-grazing in Waikato, near Hamilton. This paper reports interim data from the Waikato site on dry matter yield and botanical composition, and sward structural components of tiller density and basal cover. The plan was to sow experimental pastures in autumn of three consecutive years and take measurements 6 months after sowing (spring) and 12 months after sowing (autumn). In practice, the following sowings were conducted:

- autumn 2016 (sown 27 April), with sward measurements undertaken 12 months after sowing (autumn; spring measurements were not conducted because of unavailability of field staff).

- spring 2017 (sown 18 October), delayed from autumn due to the unusually wet conditions during the previous autumn and winter (described further, below). The sward measurements were undertaken the following autumn but in terms of pasture age the timing of measurement was at 6 months after sowing, not 12 months as planned. However, they were statistically analysed and presented in Tables along with the autumn measurements for the 2016 and 2018 sowings.

- autumn 2018 (sown 24 April), with sward measurements undertaken at 6 months after sowing (spring) and 12 months after sowing (autumn).

Thus, of the planned six data sets (three spring and three autumn), four are available (one from spring and three from autumn). For the 2016 and 2017 sowings, there are no spring yield or composition data.

The study consists of repeated annual sowings, each monitored over time. For each sowing, eight cultivars of endophyte-infected (Epichloë festucae var. lolii) perennial ryegrass (comprising different flowering dates, tetraploids and diploids, and cultivars of different decade of release as a measure of cultivar age), one cultivar of endophyte-infected (E. coenophiala) tall fescue (Festuca arundinacea), and one cultivar of endophyte-free cocksfoot (Dactylis glomerata) were drilled into a cultivated seedbed in a randomised complete block design with four replicates. The focus of the trial is on perennial ryegrass functional types and the effects of these attributes on persistence. Tall fescue and cocksfoot were included for comparison because of their generally recognised better persistence in difficult environments, but were restricted to just one cultivar of each because of finite experimental resources. 'Tribute' white clover (Trifolium repens) was broadcast sown following drilling of the grasses. Further details of the species and cultivars, endophyte strains and infection rates, flowering dates, ploidy and age of cultivars are presented in Table 1.

\section{Experimental site}

The trial is situated at the AgResearch Ruakura Research Centre, near Hamilton, on Te Kowhai silt loam soils with poor natural drainage. The entire area allocated for this long-term experiment (15 years) is currently in permanent, ryegrass-white clover-dominant pasture that is more than 20 years old (Tim Hale, Ruakura, pers comm). It has been divided nominally into fifteen subareas each of approximately 0.5 ha, one for each of the planned number of annual sowings, and each sub-area randomly pre-allocated for a sowing year. Each spring, the area allocated for sowing the following autumn was sprayed with glyphosphate, cultivated (one pass with tandem discs cutting to approximately $200 \mathrm{~mm}$ depth, power-harrow, and rolling prior to drilling if that was required) and sown into a brassica crop which was grazed in the following early autumn. It was then sprayed again, cultivated (power-harrow, plus rolling if required) and prepared for sowing. The 2017 sowing delayed from autumn to spring required an additional herbicide application and a further pass with a powerharrow prior to drilling.

Weather data were recorded at the Ruakura Weather Station, located within $250 \mathrm{~m}$ of the trial paddocks. The very wet conditions during autumn 2017 that prevented autumn sowing extended into winter and early spring (Figure 1). For the period March - May 2017, $602 \mathrm{~mm}$ of rain was recorded compared with 195 and $271 \mathrm{~mm}$ for the same periods in 2016 and 2018, respectively (30-year: $269 \mathrm{~mm}$ ). For the July - September period in 2017, $447 \mathrm{~mm}$ fell compared with 328 and $308 \mathrm{~mm}$ for the same periods in 2016 and 2018, respectively (30year mean: $325 \mathrm{~mm}$ ). During this wet period, grazing of the plots, which was completed over 24-48 h, were conducted on dry days. January - April 2019, the period leading up to the autumn measurements for the 2018 sowing, was dry with only $146 \mathrm{~mm}$ of rain, compared with the 30 -year mean of $308 \mathrm{~mm}$ for this period.

\section{Sowing and establishment}

The area for each annual sowing was 0.324 ha, comprised of 40 plots of $18 \mathrm{~m} \times 4.5 \mathrm{~m}$. Grasses were sown using a modified Oyjord plot drill (Denmark), with Great Plains disc coulters and press wheel (Great Plains Ag, Kansas, USA) at $150 \mathrm{~mm}$ spacings. Each 
Table 1 Grass species, cultivar and endophyte strain (with range in infection rates for the seed lots used 2016-2018), decade of cultivar release, ploidy, flowering date, sowing rate and source for each cultivar used.

\begin{tabular}{|c|c|c|c|c|c|c|}
\hline Grass species & $\begin{array}{c}\text { Cultivar and endophyte } \\
\text { infection }\end{array}$ & $\begin{array}{l}\text { Decade } \\
\text { of release }\end{array}$ & Ploidy & $\begin{array}{l}\text { Flowering } \\
\text { date }\end{array}$ & $\begin{array}{l}\text { Sowing } \\
\text { rate } \mathrm{kg} / \mathrm{ha}\end{array}$ & Seed source \\
\hline Perennial ryegrass & Ruanui AR95 (98\%) & $1960 s$ & Diploid & Mid & 20 & AgResearch \\
\hline Perennial ryegrass & Nui wild-type $\left(65^{1}-51 \%\right)$ & 1970s & Diploid & Mid & 20 & AgResearch \\
\hline Perennial ryegrass & Samson AR37 (99-90\%) & $1990 s$ & Diploid & Mid & 20 & Agricom \\
\hline Perennial ryegrass & Request AR37 (93 - 89\%) & $2010 s$ & Diploid & Mid & 20 & Agricom \\
\hline Perennial ryegrass & Alto AR37 (72 - 93\%) & $2000 s$ & Diploid & Late & 20 & Barenbrug \\
\hline Perennial ryegrass & Prospect AR37 (90 - 92\%) & $2010 s$ & Diploid & Late & 20 & Agricom \\
\hline Perennial ryegrass & Base AR37 (88 - 93\%) & $2010 s$ & Tetraploid & Late & 28 & PGGW Seeds \\
\hline Perennial ryegrass & Halo AR37 (90 - 94\%) & $2000 s$ & Tetraploid & Late & 28 & Agricom \\
\hline Tall fescue & Hummer MaxP тм (100 - 89\%) & $2010 s$ & & & 25 & Agricom \\
\hline Cocksfoot & Savvy & $2010 s$ & & & 10 & PGGW Seeds \\
\hline White clover & Tribute & & & & $4^{2}$ & Agricom \\
\hline
\end{tabular}

${ }^{1}$ estimated by linear interpolation for 2016 sowing based on 94\% recorded in March 2013, and 51\% in November 2017.

${ }^{2}$ bare seed equivalent.

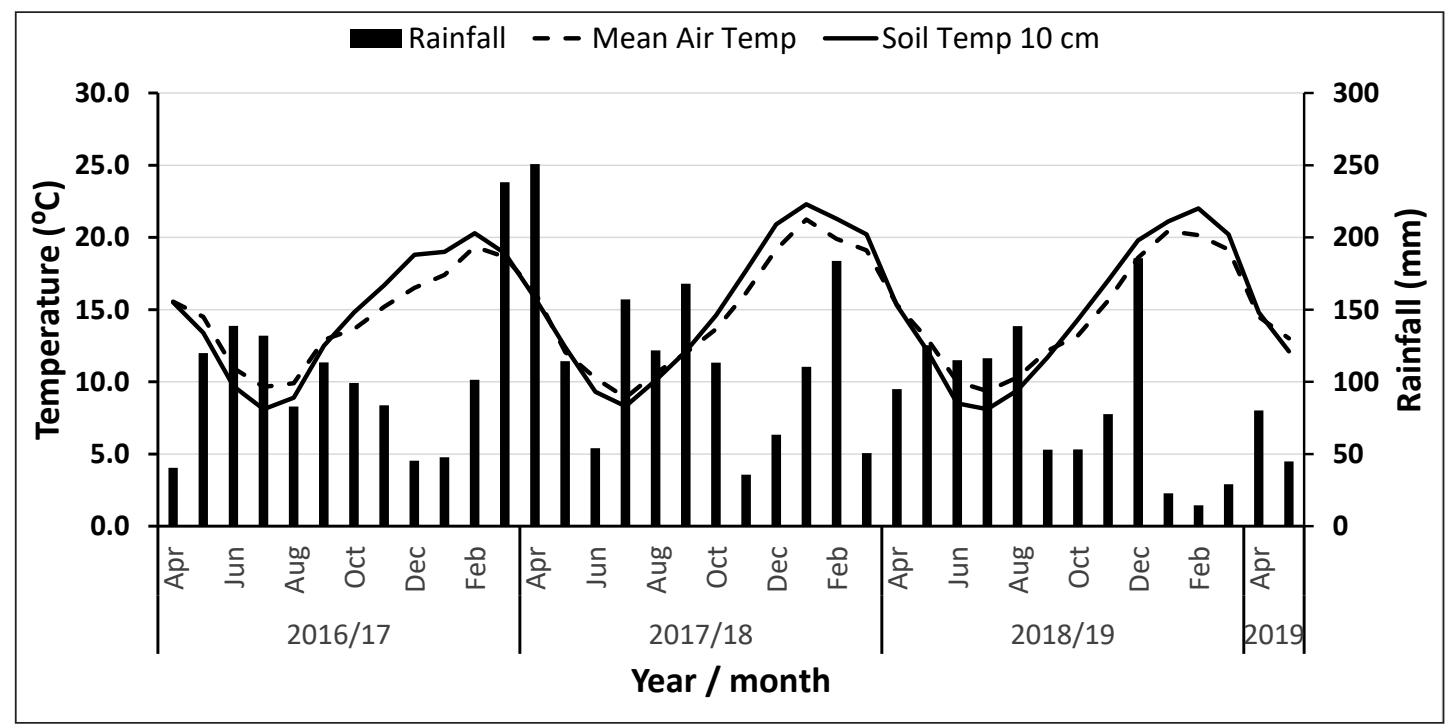

Figure 1 Monthly total rainfall, monthly mean daily temperature and monthly mean daily soil temperature at $10 \mathrm{~cm}$ soil depth for the measurement duration April 2016 - May 2019.

grass species and cultivar was sown as bare seed. Surrounding each annual sowing is a buffer zone approximately $5 \mathrm{~m}$ wide which was drilled with a mix containing equal proportions, adjusted for seed weight, of each of the sown grasses. Following this, the Superstrike ${ }^{\circledR}$ treated white clover seed was broadcast sown over the entire area of approximately 0.45 ha. Superstrike ${ }^{\circledR}$ contains rhizobia, molybdenum, lime, a nematicide and Poncho ${ }^{\circledR}$ insecticide. Plots were sown on 27 April 2016, 18 October 2017 (due to the previous wet autumn) and 24 April 2018.

\section{Grazing management}

Each annual sowing was intermittently grazed by dairy heifers. This varied from grazing the entire area of approximately 0.45 ha as a single entity, to strip grazing each replicate singly, depending on the time of year. Plots of different species and cultivars were grazed in common. The grazing protocol simulated a typical dairy rotation (Macdonald \& Penno 1998). When accumulated herbage mass reached $2600-$ $3000 \mathrm{~kg} \mathrm{DM} / \mathrm{ha}$ determined by visual assessment, plots were grazed over $24-48 \mathrm{~h}$, to leave a residual of $1500-1600 \mathrm{~kg} \mathrm{DM} / \mathrm{ha}$. For each sowing, the first 
grazing was 6 September 2016 (134 days after sowing; DAS), 6 January 2018 (80 DAS) and 10 August 2018 (108 DAS), and in the 12-month periods following each sowing there were 6,5 (plus one defoliation by mowing to aid weed control) and 8 grazings, respectively. Prior to spelling to accumulate herbage for sampling in spring or autumn, plots were topped if necessary. The areas of resident pasture reserved for future sowings are grazed according to the protocol described above.

\section{Fertiliser}

Nitrogen was applied at $30 \mathrm{~kg} \mathrm{~N} / \mathrm{ha}(65 \mathrm{~kg} / \mathrm{ha}$ SustaiN $($, Ballance Agri-Nutrients Ltd) in spring and autumn, to facilitate accumulation of regrowth for sampling. Annual maintenance fertiliser of $225 \mathrm{~kg} / \mathrm{ha}$ superphosphate $(9 \% \mathrm{P}, 11 \% \mathrm{~S})$ was applied each year in early May. In August 2017, the trial areas of the 2016-sown and the future 2017 and 2018 areas were soil-sampled individually. Lime and P, K, S fertiliser was applied to recommendation for dairy pastures to achieve soil test values within the following ranges: pH 5.8-6.0; Olsen-P 30; K 6-8, and Sulphate-S 10-12. The amounts applied in October 2017 to each area were 2016 sowing: $550 \mathrm{~kg} / \mathrm{ha}$ superphosphate $(9 \% \mathrm{P}, 11 \%$ S); 2017 sowing: $400 \mathrm{~kg} / \mathrm{ha}$ potassic superphosphate $(7 \% \mathrm{P}, 10 \% \mathrm{~K}, 8 \% \mathrm{~S}$ ) and area to be sown 2018: $280 \mathrm{~kg} /$ ha Super Selenium (24\% P, 42\% S).

\section{Pasture measurements}

Sampling methods and measurements were similar to those described in Maxwell et al. (2018). Measurements of dry matter yield and botanical composition were made once in mid-spring (24/25 October 2018, 183 DAS, for the third sowing year) and once in mid-autumn (24 27 April 2017, 362 DAS, 23/24 April 2018, 187 DAS, and 16/17 April 2019, 357 DAS, for the three sowing years, respectively). Autumn measurements included tiller density and basal cover, in addition to yield and botanical composition. Measurements were restricted to these seasons to reflect pasture growth, composition and density under, typically, the most favourable conditions for grasses, particularly ryegrasses, in spring (rising temperatures, generally adequate moisture, low prevalence of pests and disease) and under, typically, the least favourable conditions in autumn as pastures recover from stress (high temperatures and humidity, high prevalence of insect pests and diseases and low soil moisture). Annual DM production is highly correlated with these two extremes (Cosgrove 2011), and this sampling procedure is being used as a proxy for total yield that does not require yield measurement at every grazing during the year. In each season, measurements were conducted immediately prior to grazing on herbage that had accumulated to the target herbage mass. Under restricted growth conditions in autumn, if this target was not reached, plots were harvested when growth had accumulated for a maximum of six weeks.

Pasture yield was measured by mowing a single strip to $5 \mathrm{~cm}$ above ground level, along the plot ( $6 \mathrm{~m}$ long $\times 0.5 \mathrm{~m}$ wide, of $3 \mathrm{~m}^{2}$ area) and weighing the cut herbage. A minimum $200 \mathrm{~g}$ subsample was oven dried at $80^{\circ} \mathrm{C}$ for $48 \mathrm{~h}$ to determine the $\% \mathrm{DM}$ of each sample and DM yield/ha calculated. Pasture botanical composition was determined via $6-8$ hand snip samples cut from alongside the mown strip in each plot and combined into a single sample. This sample was sorted into sown grass, white clover, weeds (includes unsown grasses [predominantly temperate species Poa annua, Agrostis tenuis, Holcus lanatus and the subtropical species Digitaria sanguinalis], other clover, broadleaf species) and dead matter, and each component was oven-dried at $80^{\circ} \mathrm{C}$ for $24 \mathrm{~h}$ and weighed separately. Sown grass basal cover and tiller density were measured as indicators of sward structure. Basal cover was determined by placing a $50 \mathrm{~cm} \times$ $40 \mathrm{~cm}$ quadrat divided into $320,2.5 \mathrm{~cm} \times 2.5 \mathrm{~cm}$ cells $\left(2000 \mathrm{~cm}^{2}\right)$ in four random positions within the mown strip of each plot. The number of cells with more than half their area occupied by a sown grass plant were counted (based on Virgona \& Bowcher 2000) and expressed as a proportion of the total number. Tiller density of sown grass cultivars was determined by randomly placing a $10 \mathrm{~cm} \times 15 \mathrm{~cm}$ quadrat at right angles to drill rows in 10 random positions in each plot, and then cutting sown grass tillers inside the quadrat to ground level. Cut tillers from all 10 quadrats were combined, weighed, and 150 whole tillers randomly removed (loose leaves and daughter tillers enclosed within the parent tiller sheath were included but not counted). Non-sown grass material (other species and dead matter) was separated from sown grass material. Fresh weights for the subset of 150 counted tillers plus their loose leaves, and non-sown grass material were recorded separately, and applied to the total weight of cut herbage, to calculate tiller number per square metre.

\section{Statistical analysis}

All analyses were performed in R (R Core Team, 2020) using the "lme4" and "predictmeans" packages. For autumn data, treatment means were compared by a linear mixed effects model that included year of sowing ( 2 d.f.), cultivar ( 9 d.f.) and the year of sowing $\times$ cultivar interaction (18 d.f.) as the fixed effect and plot within year sown as the random effect. In the statistical context 'Cultivar' includes all ryegrasses, tall fescue and cocksfoot. For spring, the linear mixed effects model included just cultivar as the fixed effect and plot as the random effect. The experimental unit for each parameter was the mean value for the plot. 


\section{Results}

\section{Dry matter yield}

Spring (2018 sowing year only)

There were significant differences $(\mathrm{P}=0.002)$ in spring dry matter yield among cultivars sown in autumn 2018, with 3 distinct groupings: Request, Samson, Nui and Ruanui diploid ryegrasses and Hummer tall fescue were the highest yielding, followed by Alto and Prospect (diploids) and Base and Halo (tetraploids) ryegrasses, with Savvy cocksfoot the lowest yielding (Table 2).

\section{Autumn}

There was a significant $(\mathrm{P}=0.002)$ year of sowing $\times$ cultivar interaction for DM yield.

Year effects: Mean dry matter yield in the autumn following sowing was greater $(\mathrm{P}=0.002)$ for plots sown in 2016 than for plots sown in 2017 or 2018 , but this was not consistent for all cultivars. Ruanui, Nui and Prospect did not decline in yield across the three years. Yield of Samson ryegrass and cocksfoot was lower for plots sown in 2018 compared with 2016 or 2017. All

Table 2 The effects of year of sowing and grass cultivar on dry matter yield and cultivar ranking at harvests in the first spring and first autumn, 6 and 12 months, respectively, after each of three sowings conducted in 2016, 2017 and 2018. Means within columns with different lower-case letters differ significantly $\mathrm{P}<0.05$; means within rows (autumn only) with different uppercase letter differ significantly $\mathrm{P}<0.05$.

\begin{tabular}{|c|c|c|c|c|c|c|c|c|c|}
\hline \multirow{2}{*}{ Parameter } & \multirow[t]{2}{*}{ Season } & \multirow[t]{2}{*}{ Cultivar ${ }^{1}$} & \multicolumn{3}{|c|}{ Year and season sown } & \multicolumn{3}{|c|}{ Cultivar ranking } & \multirow[b]{2}{*}{2018} \\
\hline & & & $\begin{array}{c}2016 \\
\text { Autumn }\end{array}$ & $\begin{array}{c}2017 \\
\text { Spring }\end{array}$ & $\begin{array}{c}2018 \\
\text { Autumn }\end{array}$ & Mean & $2016^{2}$ & $2017^{2}$ & \\
\hline \multirow[t]{28}{*}{ DM yield } & Spring & Alto & - & - & 1210 bcde & - & - & - & 6 \\
\hline & & Base & - & - & 1130 cde & - & - & - & 8 \\
\hline & & Halo & - & - & 1040 de & - & - & - & 9 \\
\hline & & Hummer & - & - & $1320 \mathrm{abcd}$ & - & - & - & 5 \\
\hline & & Nui & - & - & $1520 a b$ & - & - & - & 2 \\
\hline & & Prospect & - & - & 1200 bcde & - & - & - & 7 \\
\hline & & Request & - & - & $1620 \mathrm{a}$ & - & - & - & 1 \\
\hline & & Ruanui & - & - & $1420 \mathrm{abc}$ & - & - & - & 4 \\
\hline & & Samson & - & - & $1550 a b$ & - & - & - & 3 \\
\hline & & Savvy & - & - & $880 \mathrm{e}$ & - & - & - & 10 \\
\hline & & Mean & - & - & 1290 & & & & \\
\hline & & $\mathrm{P}$ & & & 0.002 & & & & \\
\hline & & SEM & & & 121.7 & & & & \\
\hline & Autumn & Alto & 500 bc A & $280 \mathrm{~cd} \mathrm{~B}$ & 380 a $A B$ & 390 & 4 & 8 & 1 \\
\hline & & Base & $450 \mathrm{bcd} A$ & $310 \mathrm{abcd} A B$ & 230 bcd B & 330 & 6 & 6 & 7 \\
\hline & & Halo & 720 a A & $370 \mathrm{abcB}$ & $230 \mathrm{bcd} B$ & 440 & 1 & 5 & 6 \\
\hline & & Hummer & $540 \mathrm{bc} \mathrm{A}$ & 400 abc AB & $350 a b B$ & 430 & 3 & 4 & 2 \\
\hline & & Nui & $230 \mathrm{~d} A$ & $270 \mathrm{~cd} \mathrm{~A}$ & 140 de $A$ & 210 & 10 & 9 & 9 \\
\hline & & Prospect & $440 \mathrm{~cd} \mathrm{~A}$ & $430 \mathrm{ab} A$ & $350 \mathrm{ab} A$ & 410 & 7 & 2 & 3 \\
\hline & & Request & $590 \mathrm{ab} A$ & $430 a b B$ & 290 abc B & 440 & 2 & 3 & 4 \\
\hline & & Ruanui & 300 e A & $220 \mathrm{~d} A$ & 190 cde A & 240 & 9 & 10 & 8 \\
\hline & & Samson & $470 \mathrm{bc} \mathrm{A}$ & 450 a $A$ & 270 abcd B & 400 & 5 & 1 & 5 \\
\hline & & Savvy & 330 de $A$ & $300 \mathrm{bcd} A$ & 80 e B & 240 & 8 & 7 & 10 \\
\hline & & Mean & 460 & 350 & 252 & & & & \\
\hline & & P-cultivar & & $<0.001$ & & & & & \\
\hline & & P-year sown & & 0.002 & & & & & \\
\hline & & P-cultivar $\times$ year sown & & 0.002 & & & & & \\
\hline & & SEM & & 53.8 & & & & & \\
\hline
\end{tabular}

\footnotetext{
1 'Cultivar' is comprised of eight cultivars of perennial ryegrass, one cultivar of tall fescue (Hummer) and one of cocksfoot (Savvy).
}

2 Data not collected in spring 2016, and for 2017 plots not sown until spring. 
other cultivars of ryegrass and tall fescue were lower yielding for both 2017 and 2018 sowing years.

Cultivar effects: The significant interaction for year of sowing $\times$ cultivar $(\mathrm{P}=0.002)$ indicated there was substantial re-ranking of cultivars among sowing years. Samson, Request and tall fescue consistently ranked highly and Ruanui, Nui and cocksfoot consistently ranked lowly, however, other cultivars were inconsistent in their ranking.
Nui and Ruanui ranked with the highest yielding group of cultivars in spring but were the lowest yielding cultivars in autumn.

\section{Proportions of sown grass and white clover}

For the plots sown in 2018, there were significant differences among cultivars in the proportions of sown grass $(\mathrm{P}=0.004)$ and white clover $(\mathrm{P}<0.001)$ in spring (Table 3 ). Compared with ryegrass cultivars, the

Table 3 The effects of year of sowing and grass cultivar on proportions (\% dry matter) of sown grass and white clover at harvests in the first spring and first autumn, 6 and 12 months, respectively, after each of three sowings conducted in 2016, 2017 and 2018. Means within columns with different lower-case letters differ significantly $\mathrm{P}<0.05$; means within rows (autumn only) with different upper-case letter differ significantly $\mathrm{P}<0.05$.

\begin{tabular}{|c|c|c|c|c|c|c|c|c|c|}
\hline \multirow{3}{*}{ Season } & \multirow{3}{*}{ Cultivar ${ }^{1}$} & \multicolumn{4}{|c|}{ Sown grass } & \multicolumn{4}{|c|}{ White clover } \\
\hline & & \multicolumn{3}{|c|}{ Year and season sown } & \multirow[b]{2}{*}{ Mean } & \multicolumn{3}{|c|}{ Year and season sown } & \multirow[b]{2}{*}{ Mean } \\
\hline & & $\begin{array}{c}2016 \\
\text { Autumn }\end{array}$ & $\begin{array}{c}2017 \\
\text { Spring }\end{array}$ & $\begin{array}{c}2018 \\
\text { Autumn }\end{array}$ & & $\begin{array}{c}2016^{2} \\
\text { Autumn }\end{array}$ & $\begin{array}{l}2017^{2} \\
\text { Spring }\end{array}$ & $\begin{array}{c}2018 \\
\text { Autumn }\end{array}$ & \\
\hline \multirow[t]{13}{*}{ Spring } & Alto & - & - & $87.6 \mathrm{a}$ & - & - & - & $4.9 \mathrm{~b}$ & - \\
\hline & Base & - & - & $88.0 \mathrm{a}$ & - & - & - & $4.8 \mathrm{~b}$ & - \\
\hline & Halo & - & - & $91.7 \mathrm{a}$ & - & - & - & $4.6 \mathrm{~b}$ & - \\
\hline & Hummer & - & - & $72.6 \mathrm{~b}$ & - & - & - & $7.5 b$ & - \\
\hline & Nui & - & - & $89.0 \mathrm{a}$ & - & - & - & $5.3 \mathrm{~b}$ & - \\
\hline & Prospect & - & - & $90.4 \mathrm{a}$ & - & - & - & $1.8 \mathrm{~b}$ & - \\
\hline & Request & - & - & $92.7 \mathrm{a}$ & - & - & - & $2.8 b$ & - \\
\hline & Ruanui & - & - & $88.0 \mathrm{a}$ & - & - & - & $4.7 \mathrm{~b}$ & - \\
\hline & Samson & - & - & $91.7 \mathrm{a}$ & - & - & - & $2.0 \mathrm{~b}$ & - \\
\hline & Savvy & - & - & $67.9 \mathrm{~b}$ & - & - & - & $20.1 \mathrm{a}$ & - \\
\hline & Mean & - & - & $86.0 \mathrm{a}$ & - & - & - & 5.8 & - \\
\hline & $\mathrm{P}$ & & & 0.004 & & & & $<0.001$ & \\
\hline & SEM & & & 4.51 & & & & 2.65 & \\
\hline \multirow[t]{15}{*}{ Autumn } & Alto & $63.0 \mathrm{abc} A$ & $68.2 \mathrm{ab} A$ & 76.0 a A & 69.0 & 7.4 a A & $8.8 \mathrm{~b} \mathrm{~A}$ & $14.8 \mathrm{c} \mathrm{A}$ & 10.5 \\
\hline & Base & 78.0 a A & $71.2 \mathrm{ab} A$ & 78.7 a A & 76.0 & 5.6 a A & $4.3 \mathrm{~b} \mathrm{~A}$ & $12.6 \mathrm{c} \mathrm{A}$ & 7.5 \\
\hline & Halo & $72.0 \mathrm{ab} A$ & 74.5 a A & $68.4 \mathrm{ab} A$ & 71.5 & 8.9 a $A B$ & $2.5 \mathrm{~b} \mathrm{~B}$ & 20.1 c A & 10.5 \\
\hline & Hummer & $68.0 \mathrm{ab} A$ & 76.0 a A & 81.3 a A & 75.0 & 9.7 a A & $7.5 \mathrm{~b} \mathrm{~A}$ & $11.3 \mathrm{c} \mathrm{A}$ & 9.5 \\
\hline & Nui & 48.5 c A & $52.5 \mathrm{~b} \mathrm{~A}$ & $50.9 \mathrm{bc} \mathrm{A}$ & 50.5 & 10.7 a B & 24.0 a A & $35.4 \mathrm{~b} \mathrm{~A}$ & 23.5 \\
\hline & Prospect & $65.8 \mathrm{abc} A$ & $65.8 \mathrm{ab} A$ & $68.4 \mathrm{ab} A$ & 66.5 & 3.7 a B & $3.5 \mathrm{~b} \mathrm{~B}$ & 19.3 c A & 9.0 \\
\hline & Request & 80.2 a $A B$ & 62.8 b B & 86.1 a A & 76.5 & 3.8 a A & $8.3 \mathrm{~b} \mathrm{~A}$ & $8.9 \mathrm{cA}$ & 7.0 \\
\hline & Ruanui & 54.3 bc B & 55.0 b B & 79.2 a A & 63.0 & 9.8 a A & $13.0 \mathrm{ab} \mathrm{A}$ & $13.8 \mathrm{c} \mathrm{A}$ & 12.0 \\
\hline & Samson & $53.5 \mathrm{bc} \mathrm{B}$ & 74.2 a A & 84.3 a A & 70.5 & $11.1 \mathrm{a} \mathrm{A}$ & $8.0 \mathrm{~b} \mathrm{~A}$ & $10.0 \mathrm{cA}$ & 9.5 \\
\hline & Savvy & $19.4 \mathrm{~d} C$ & 78.0 a $A$ & 39.8 c B & 45.5 & 11.8 a B & $2.3 \mathrm{~b} \mathrm{~B}$ & 51.3 a A & 22.0 \\
\hline & Mean & 60.3 & 67.8 & 71.3 & 66.5 & 8.3 & 8.2 & 19.7 & 12.0 \\
\hline & P-cultivar & & $<0.001$ & & & & $<0.001$ & & \\
\hline & P-year sown & & 0.002 & & & & $<0.001$ & & \\
\hline & P-cultivar $\times$ year sowr & & $<0.001$ & & & & $<0.001$ & & \\
\hline & SEM & & 7.00 & & & & 4.83 & & \\
\hline
\end{tabular}

1 'Cultivar' is comprised of eight cultivars of perennial ryegrass, one cultivar of tall fescue (Hummer) and one of cocksfoot (Savvy).

2 Data not collected in spring 2016, and for 2017 plots not sown until spring. 
proportions of sown grass were lower for tall fescue and cocksfoot, and the proportion of white clover was higher for cocksfoot.

In autumn, the overall mean proportion of sown species (grass plus white clover) was lowest for plots sown in $2016(69 \%)$, intermediate for plots sown in 2017 (76\%) and highest for plots sown in 2018 (91\%). Similarly, the proportion of sown grass in autumn was lowest for plots sown in 2016, intermediate for 2017 and highest for plots sown in $2018(\mathrm{P}<0.001)$. This was largely due to the increasing proportion across sowing years of sown grass for some cultivars (year sown $\times$ cultivar interaction $\mathrm{P}<0.001)$. Compared with other cultivars of ryegrass and tall fescue, the proportion of sown grass was low for Nui, Ruanui, Samson and cocksfoot sown in 2016, but for Samson and cocksfoot was higher when sown in 2017 and for Samson and Ruanui was higher when sown in 2018. The interaction of year sown $\times$ cultivar was significant for the proportion of white clover $(\mathrm{P}<0.001)$. The proportion of white clover was similar for all cultivars of ryegrass and tall fescue and cocksfoot sown in 2016. For plots sown in 2017 the proportion of white clover was higher for Nui than any other cultivars of ryegrass except for Ruanui, and higher than tall fescue and cocksfoot.
For plots sown in 2018 the proportion of clover was higher for cocksfoot and Nui ryegrass than for the other cultivars of ryegrass and tall fescue.

\section{Tiller density}

Overall, tiller densities in autumn were similar for plots sown in 2017 and 2018, and higher than for plots sown in 2016 ( $\mathrm{P}=0.032$; Table 4). Nui, tall fescue and cocksfoot had the lowest tiller densities, and Prospect, Request and Samson had the highest densities when sown in 2016 and 2017 (year sown $\times$ cultivar interaction $\mathrm{P}=0.014$ ). However, when sown in 2018 , tiller density of tall fescue was higher, and the density of Prospect was lower such that they were similar to each other and intermediate to the high-density and low-density groups of cultivars. When sown in 2018, the tetraploids Base and Halo, had lower tiller densities than the other cultivars of ryegrass.

\section{Basal cover}

While there was no significant difference among sowing years for basal cover $(\mathrm{P}=0.106)$, the year sown $\times$ cultivar interaction $(\mathrm{P}<0.001)$ resulted from the differences among cultivars and the different ranking of cultivars across years (Table 4). Nui consistently

Table 4 The effects of year of sowing and grass cultivar on sown grass tiller density (tillers $/ \mathrm{m} 2)$ and basal cover (\% ground cover of sown grass species or cultivar) measured in autumn 12 months after each of three sowings conducted in 2016, 2017 and 2018. Means within columns with different lower-case letters differ significantly $\mathrm{P}<0.05$; means within rows (autumn only) with different upper-case letter differ significantly $\mathrm{P}<0.05$.

\begin{tabular}{|c|c|c|c|c|c|c|c|c|}
\hline \multirow[b]{3}{*}{ Cultivar ${ }^{1}$} & \multicolumn{4}{|c|}{ Sown grass tiller density } & \multicolumn{4}{|c|}{ Basal cover } \\
\hline & \multicolumn{3}{|c|}{ Year and season sown } & \multirow[b]{2}{*}{ Mean } & \multicolumn{3}{|c|}{ Year and season sown } & \multirow[b]{2}{*}{ Mean } \\
\hline & $\begin{array}{c}2016 \\
\text { Autumn }\end{array}$ & $\begin{array}{c}2017 \\
\text { Spring }\end{array}$ & $\begin{array}{c}2018 \\
\text { Autumn }\end{array}$ & & $\begin{array}{c}2016 \\
\text { Autumn }\end{array}$ & $\begin{array}{c}2017 \\
\text { Spring }\end{array}$ & $\begin{array}{c}2018 \\
\text { Autumn }\end{array}$ & \\
\hline Alto & $1970 a b B$ & 3300 bc AB & $3730 \mathrm{abc} A$ & 3000 & $19.2 a b A B$ & 15.2 a B & $22.0 \mathrm{bc} \mathrm{A}$ & 18.8 \\
\hline Base & $1980 \mathrm{ab} A$ & $2950 \mathrm{~cd} \mathrm{~A}$ & $2000 \operatorname{efg} A$ & 2310 & 13.3 de $A$ & $14.3 \mathrm{ab} A$ & 17.1 ef $A$ & 14.9 \\
\hline Halo & $1610 \mathrm{abc} A$ & 2990 c A & $2440 \operatorname{def} A$ & 2340 & $17.1 \mathrm{bcd} A$ & $13.7 \mathrm{ab} A$ & $17.4 \operatorname{def} A$ & 16.1 \\
\hline Hummer & $660 \mathrm{~cd} \mathrm{~B}$ & 1810 de $A B$ & 3080 cde A & 1850 & 10.5 e B & $14.4 \mathrm{ab} \mathrm{A}$ & 18.2 cdef $A$ & 14.4 \\
\hline Nui & 870 bcd A & 1760 e A & $1720 \mathrm{fg} A$ & 1450 & 11.1 e A & $10.0 \mathrm{~b} \mathrm{~A}$ & $14.0 \mathrm{fA}$ & 11.7 \\
\hline Prospect & 2060 a B & 4640 a A & $3520 \mathrm{bcd} A B$ & 3410 & $18.3 \mathrm{bc} \mathrm{A}$ & 17.6 a A & $21.6 \mathrm{bcd} A$ & 19.2 \\
\hline Request & 2380 a B & $4200 \mathrm{ab} A$ & 4770 a A & 3780 & 22.9 a $A B$ & 18.1 a B & $24.5 \mathrm{ab} A$ & 21.8 \\
\hline Ruanui & 1470 abcd B & 3700 abc A & 3110 cde A & 2460 & 14.0 cde B & 16.0 a $A B$ & 21.4 bcde $\mathrm{A}$ & 17.1 \\
\hline Samson & 2100 a B & 3570 abc $A B$ & $4440 a b$ A & 3370 & $20.1 \mathrm{ab} B$ & 17.3 a B & 26.7 a A & 21.4 \\
\hline Savvy & $330 \mathrm{~d} B$ & 2850 cde A & $870 \mathrm{~g} \mathrm{~B}$ & 1350 & $5.3 f B$ & 17.3 a A & $7.8 \mathrm{~g} \mathrm{~B}$ & 10.1 \\
\hline Mean & 1540 & 3180 & 2970 & 2560 & 15.2 & 15.4 & 19.1 & 16.5 \\
\hline P-cultivar & & $<0.001$ & & & & $<0.001$ & & \\
\hline P-year sown & & 0.032 & & & & 0.106 & & \\
\hline P cultivar $\times$ yea & sown & 0.014 & & & & $<0.001$ & & \\
\hline SEM & & 553.0 & & & & 1.98 & & \\
\hline
\end{tabular}

1 'Cultivar' is comprised of eight cultivars of perennial ryegrass, one cultivar of tall fescue (Hummer) and one of cocksfoot (Savvy). 
had low basal cover across all sowing years, as did tall fescue when sown in 2016. Cocksfoot had low basal cover for sowings in 2016 and 2018, but when sown in 2017 (spring) it was similar to all ryegrass cultivars and tall fescue. Samson and Request were consistently highest ranked for basal cover, while the tetraploids, Base and Halo, were low ranked for plots sown in 2018, and Base was low ranked for plots sown in 2016.

\section{Discussion}

The experiment was designed to account for the interacting effects imposed by establishment-year conditions and age of pasture when subsequent biotic and abiotic stressors occur, and structured to identify functional characteristics of ryegrass that are associated with persistence. By including contrasting grass species and ryegrass cultivars of different functional types and age, hypotheses relating to morphological characteristics can be tested to identify factors that are important for persistence. The preliminary results presented in this paper focus on the effects of different establishment years on sward development in the first 12 months; subsequent papers will report longer-term effects as repeated sowings and monitoring continue.

\section{Year effects}

Spring data were not collected following the autumn sowing in 2016 and, in 2017, plots were not sown until spring, so there are only autumn data available for that sowing year. Thus, year effects were measurable only for autumn data. Despite the incomplete spring DM yields and botanical proportions data, the tables have been structured so that the experimental design is clear and the available data can be readily compared with equivalent data from the Canterbury site (Maxwell et al. 2018). The lower first-autumn total yield for each successive sowing was offset by increasing proportions of sown species, and greater tiller density and basal cover. This was despite the very low rainfall of 146 $\mathrm{mm}$ (compared with the 30 -year mean of $308 \mathrm{~mm}$ ) for the January - April period of 2019 preceding when the autumn data for the 2018 sowing were collected. This suggests that even though the drought suppressed dry matter yield, the 12-month-old pasture tolerated the drought conditions in terms of botanical composition and sward structure. As a consequence of the delayed sowing for 2017, the autumn measurements conducted in 2018 were on pasture that was approximately 6-months old, not 12-months-old as for the 2016 and 2018 sowing years. However, with the exception of the high proportion of sown species, high tiller density and high basal cover for cocksfoot, there were no obvious effects of the delayed sowing among the ryegrass cultivars or tall fescue. For the 2017 sowing year, cocksfoot was the dominant component in contrast to it being a minor component for the sowings conducted in 2016 and 2018.

The tiller density measured in autumn was substantially lower for plots sown in 2016 compared with either 2017 or 2018. This may have been a consequence of the greater number of days from sowing to the first grazing in 2016 and the higher herbage mass at sampling in autumn. Both factors would tend to lead to lower tiller densities, although typically lower densities are associated with larger tiller size. (e.g. Grant et al. 1983; Davies et al. 1988; HernandezGaray et al. 1999). The similarity in basal cover across years also supports that at lower densities tiller size was larger. These effects indicate that very different pasture botanical and structural compositions are set up in different sowing years. The resulting differences in establishment may have consequences for the stability of sown species yield and the future resilience of these plots exposed to unpredictable and episodic, biotic and abiotic stressors. This relationship between early and medium-term yield has been identified as a measure of persistence that may be a suitable trait for cultivar ranking in the Forage Value Index (Dodd et al. 2018). Significant year-to-year variation in establishment was also noted by Maxwell et al. (2018) for the Canterbury trial. While the longer-term consequences of this can not be quantified from the data currently available, a feature of this trial design is that this will be possible to quantify as long-term monitoring of each sowing year progresses. For example, the effects of the 2019 autumn drought on the one-year-old pasture sown in 2018 were noted above. The effects of that same drought will be able to be compared across the three-year-old pasture that was sown in 2016, the two-year-old pasture that was sown in 2017, the one-year-old pasture that was sown in 2018 (this manuscript), and the set of treatments newly sown in autumn 2019.

\section{Ryegrass cultivars}

The eight ryegrass cultivars were selected to represent different functional types available commercially (ploidy, flowering date) and decade of release as a measure of cultivar age. Of these functional types, ploidy appears to have affected some of the measured parameters (data not presented in this manner in the Tables, but it can be derived by comparing the means over the three years of Alto and Prospect (late-flowering diploids) with the means of Base and Halo (tetraploids with comparable late-flowering dates). In autumn, the diploids had greater tiller density ( 3200 vs 2300 tillers $/ \mathrm{m}^{2}$ ) and basal cover (19 vs $15 \%)$ than the tetraploids, as expected (Tozer et al. 2014a), but a lower proportion of sown grass ( 68 vs $74 \%$ ). The mid-flowering diploids (Samson and Request) had higher dry matter yield in spring than the late-flowering diploids (Alto and Prospect), as seen in other studies 
(Chapman et al. 2018), although late-flowering cultivars currently dominate the higher-ranking bands in the FVI in annual yield and in summer and autumn yield. In this interim data, flowering-date effects should be treated with some caution. There was only a single harvest date (late October) which may not account for the higher yield potential of late-flowering cultivars later in spring, and there was just one year of spring data. Differences in flowering date did not affect yield in autumn. When diploid cultivars were divided into three groups based on decade of release, 'old' (1960s and 1970s; Ruanui and Nui), 'intermediate' (1990s and 2000s; Samson and Alto) and 'new' (2010s; Request and Prospect), there was no obvious effect of age of cultivar, as reported for a comparable study by Lee et al. (2017). Intermediate-age cultivars had higher mean values for each parameter, but means for the 'old' cultivars were reduced by the poor performance of Nui, possibly related to its low endophyte infection level. For the ryegrass cultivars used in this study, there was no obvious inverse relationship between yield and tiller density across cultivars (or functional types; see discussion above under Year effects), as was seen in the companion study continuously stocked with sheep in Canterbury (Maxwell et al. 2018), and many other studies.

\section{Species effects}

Tall fescue is a slow establishing species (Easton \& Pennell 1993) and it is normally recommended that this species is sown in spring, as is cocksfoot, because both have greater thermal time requirements for germination and emergence than ryegrass (Moot et al. 2000). For this experiment, both species were sown in autumn to avoid the confounding between grass species and sowing season. There was some evidence of slower establishment of tall fescue, from the lower proportion of the sown grass in spring following sowing in 2018, and the lower tiller densities and basal cover in autumn following the sowings in 2016 and 2017. Tozer et al. (2014b) reported even slower establishment of tall fescue, with ryegrass still superior to tall fescue at suppressing unsown species three years after sowing. However, for the 2018 sowing in this experiment, the proportion of sown grass, tiller density and basal cover of tall fescue were equivalent to most of the ryegrasses. There is no clear reason why tall fescue established better in 2018 than in 2016 or 2017. Possibly the greater rainfall in April 2018 (95 mm) was more favourable than the drier April 2016 (40 mm), although cocksfoot did not benefit similarly. Cocksfoot was slow to establish with low yield, proportion of sown grass, tiller density and basal cover. However, despite the low yield when sown in 2017 it did have a high proportion of sown grass, and the highest proportion of white clover in spring and autumn following the sowing in 2018.

\section{Endophyte}

Seed of proprietary cultivars was provided annually from Seed Company stocks. With the exception of Alto at $72 \%$ in 2016, endophyte infection levels were consistently high at $90 \%$ or above, well above the minimum $70 \%$ required for commercial sale as 'highendophyte' cultivars. Ruanui was first released in the 1960 s, before endophyte had been identified and its functions understood. From old reports of ryegrass staggers-like symptoms it is known that it contained wild-type endophyte (now commonly called standard endophyte), although infection was lost when nucleus seed was re-multiplied in 1972 after being stored for a decade (Latch \& Christensen 1982). For this experiment it was deemed necessary for valid cultivar comparisons that Ruanui should contain endophyte, and that it be a wild-type strain considered representative of what was prevalent at that time. Seed of Ruanui was obtained from the Margot Forde Germplasm Centre (AgResearch, Palmerston North), inoculated with endophyte strain AR95, a selected analogue of wildtype, and the seed multiplied. Nui seed was obtained from stocks maintained by Grasslanz Technology Ltd. While there is no minimum endophyte infection status required for supply of this public cultivar, it was $94 \%$ when tested in March 2013, but had dropped to 51\% by November 2017. It appears that the performance of this cultivar (low basal cover and low tiller density, and low proportion of the sown grass and low yield in autumn) was affected by the endophyte infection level declining below the $70 \%$ considered necessary for effective plant protection (Hume \& Barker 2005).

\section{Conclusions}

The year-to-year variation in establishment success and different cultivar rankings demonstrated in this experiment to date may have important influences on persistence. Systematically accounting for these effects will be possible as this experiment continues. This will provide information on the plant functional traits and their interactions with environmental factors that affect persistence of grass species and cultivars. Furthermore, it will be useful for plant breeding and management efforts to improve persistence, and has the potential to help in cultivar ranking systems such as the Forage Value Index.

\section{ACKNOWLEDGEMENTS}

Sarah McKenzie, Agricom, and Janet Montgomery, Kris Bailey and Mark Shand, Barenbrug NZ, for annually supplying high specification seed of the cultivars for which their respective companies are the head licensees. Thanks to David Chapman, DairyNZ, and Jim Crush, AgResearch, for support to initiate this experiment, to David Hume for advising on the 
endophyte selection and inoculation for Ruanui ryegrass and to Catherine Cameron for providing the weather data for the experimental site. Thanks also to Shaun Monk and Grasslanz Technology Ltd for supply of Nui seed and multiplication of Ruanui, and to Tim Hale, Farm Operations Manager, Ruakura for supervising cultivation and grazing management. Funding to date has been provided by DairyNZ Inc and the AgResearch Strategic Science Investment Fund.

\section{REFERENCES}

Cosgrove GP. 2011. Long-term trends in production and composition of ryegrass-white clover pasture intensively grazed by dairy-beef cattle. Pasture Persistence Symposium. Grassland Research and Practice Series 15. New Zealand Grassland Association. pp.53-62.

Chapman DF, Edwards GR, Nie ZN. 2011. Plant responses to climate and relationships with pasture persistence. Pasture Persistence Symposium. Grassland Research and Practice Series 15. New Zealand Grassland Association. pp. 99-107.

Chapman DF, Muir PD, Faville MJ. 2015. Persistence of dry matter yield among New Zealand perennial ryegrass (Lolium perenne L.) cultivars: insights from a long-term data set. Journal of New Zealand Grasslands 77: 177-184. https://doi.org/10.33584/ jnzg.2015.77.463

Chapman DF, Bryant JR, Olayemi ME, Edwards GR, Thorrold BS, McMillan WH, Kerr GA, Judson G, Cookson T, Moorhead A, Norriss M. 2017. An economically based evaluation index for perennial and short-term ryegrasses in New Zealand dairy farm systems. Grass and Forage Science 72: 1-21. https:// doi.org/10.1111/gfs.12213

Chapman DF, Crush JR, Lee JM, Cosgrove GP, Stevens DR, Rossi L, Popay AJ, Edwards GR, King WM. 2018. Implications of grass-clover interactions in dairy pastures for forage value indexing systems. 6. Cross-site analysis and general discussion. New Zealand Journal of Agricultural Research 61: 255284. https://doi.org/10.1080/00288233.2018.14428 68

Clark DA. 2011. Changes in pastoral farming practices and pasture persistence - a review. Pasture Persistence Symposium. Grassland Research and Practice Series 15. New Zealand Grassland Association. pp. 7-13.

Davies A. 1988. The regrowth of grass swards. Pp 85-127. In: The grass crop: the physiological basis of production. In: Jones MB, Lazenby A. (Eds.). London, UK.: Chapman and Hall. https://doi. org/10.1007/978-94-009-1187-1_3

Dodd MB, Chapman DF, Ludemann CI, Griffiths W, Tozer KN, Donnelly L. 2018. The measurement of perennial ryegrass persistence. Journal of New Zealand Grasslands 80: 161-168. https://doi. org/10.33584/jnzg.2018.80.339

Easton HS, Pennell CG. 1993. Breeding tall fescue for establishment vigour. Proceedings of the New Zealand Grassland Association 55:151-154. https:// doi.org/10.33584/jnzg.1993.55.2094

Edwards GR, Chapman DF 2011. Plant responses to defoliation and relationships with pasture persistence. Pasture Persistence Symposium. Grassland Research and Practice Series 15. New Zealand Grassland Association. pp. 39-46.

Grant SA, Barthram GT, Torvell L, King J, Smith HK. 1983. Sward management, lamina turnover and tiller population density in continuously stocked Lolium perenne-dominated swards. Grass Forage Science 38: 333-344. https://doi.org/10.1111/j.1365-2494.1983. tb01657.x

Hernandez-Garay A, Matthew C, Hodgson J. 1999. Tiller size/density compensation in perennial ryegrass miniature swards subject to differing defoliation heights and a proposed productivity index. Grass and Forage Science 54: 347-356. https://doi.org/10.1046/ j.1365-2494.1999.00187.x

Hume DE, Barker DJ. 2005. Growth and management of endophytic grasses in pastoral agriculture. In: Roberts CA, West CP, Spiers DE (Eds.). Neotyphodium in Cool-Season Grasses. Ames, IA, USA: Blackwell Publishing Ltd. pp. 201-226.

Latch GCM, Christensen MJ. 1982. Ryegrass endophyte, incidence, and control. New Zealand Journal of Agricultural Research 25: 443-448. https://doi.org/10.1080/00288233.1982.10417910

Lee JM, Thom ER, Wynn K, Waugh D, Rossi L, Chapman DF. 2017. High perennial ryegrass seeding rates reduce plant size and survival during the first year after sowing: does this have implications for pasture sward persistence. Grass and Forage Science 72: 382-400. https://doi.org/10.1111/gfs.12243

Lee JM, Thom ER, Chapman DF, Wynn K, Waugh D, Rossi L, Faville MJ, McNeil MR. 2018. High perennial ryegrass seeding rates do not negatively impact pasture sward persistence. Grass and Forage Science 73: 456472. https://doi.org/10.1111/gfs. 12335

Macdonald KA, Penno JW. 1998. Management decision rules to optimise milksolids production on dairy farms. Proceedings of the New Zealand Society of Animal Production 58: 132-135.

Maxwell TMR, Edwards GR, Cosgrove GP 2018. Persistence of ryegrass, tall fescue and cocksfoot following sequential annual sowings: pasture yield, composition and density in three establishment years under sheep grazing in Canterbury. Journal of New Zealand Grasslands 80: 169-176. https://doi. org/10.33584/jnzg.2018.80.289 
Mercer CF. 2011. (Ed.) Pasture Persistence Symposium. Grassland Research and Practice Series 15. New Zealand Grassland Association. $230 \mathrm{p}$.

Moot DJ, Scott WR, Roy AM, Nicholls AC. 2000. Base temperature and thermal time requirements for germination and emergence of temperate pasture species. New Zealand Journal of Agricultural Research 43: 15-25. https://doi.org/10.1080/002882 33.2000.9513404

R Core Team. 2020. R: A language and environment for statistical computing. R Foundation for Statistical Computing, Vienna, Austria. https://www.R-project. org/

Thom ER, Fraser TJ, Hume DE. 2011. Sowing methods for successful pasture establishment - a review. Pasture Persistence Symposium. Grassland Research and Practice Series 15. New Zealand Grassland Association. pp. 31-37.

Thom ER, Waugh CD, McCabe RJ. 1998. Growth and persistence of perennial and hybrid ryegrasses when grazed by dairy cows in the central Waikato region of New Zealand. New Zealand Journal of Agricultural Research 41: 477-486. https://doi.org/10.1080/00288 233.1998.9513331
Tozer KN, Cameron CA, Thom ER. 2011. Pasture persistence: farmer observations and field measurements. Pasture Persistence Symposium. Grasslands Research and Practice Series 15. New Zealand Grassland Association. pp. 25-30.

Tozer KN, Chapman DF, Bell NL, Crush JR, King WM, Rennie GM, Wilson DJ, Mapp NR, Rossi L, Aalders LT, Cameron CA. 2014a. Botanical survey of perennial ryegrass-based dairy pastures in three regions of New Zealand: implications for pasture persistence. New Zealand Journal of Agricultural Research 57: 14-29. https://doi.org/10.1080/002882 33.2013 .863785

Tozer KN, Minnee EMK, Cameron CA. 2014b. Performance of sown species in weed ingress in new dairy pastures based on tall fescue and perennial ryegrass. New Zealand Plant Protection 67: 231-237. https://doi.org/10.30843/nzpp.2014.67.5785

Virgona JM, Bowcher A. 2000. Effects of grazing interval on basal cover of four perennial grasses in a summer-dry environment. Australian Journal of Experimental Agriculture 40: 299-311. https://doi. org/10.1071/EA98015 